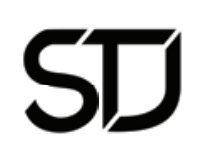

\title{
He was with God and was God?
}

\author{
Jan van der Watt \\ University of the Free State, Bloemfontein, South Africa \\ jgvdw100@gmail.com
}

\begin{abstract}
The word $\theta \varepsilon$ co is used for both the Father and the Son in the Gospel of John. How should this be understood? After an analysis of the different uses of this word for the Son it is concluded that such a use is based on an intimate relation between the Father and Son which is expressed in functional unity as well as unity of will and thought. The claims of the Jewish opponents that Jesus makes himself God and is therefore a blasphemer are then considered. The Jewish opponents blame Jesus for trespassing against or even threatening the sovereignty of the only God of Israel. The conceptions about heavenly or angelic rulers that threaten one another are considered against John's strong imagery and language that indicates the non-threatening relationship between God, the Father and God, the Son.
\end{abstract}

Key words

Christology in John; God; Jesus as God; John 1:1,18; 20:28; My Lord and my God

\section{Introduction}

After the remark of Nils Dahl (1975:5; cf. also Keck 1986:363) that God is a neglected topic in New Testament studies, more attention was paid to this aspect of New Testament theology. Johannine studies were no exception. Marianne Meye Thompson $(2001)^{1}$ wrote what could today still be considered the standard work on God in John, while Francois Tolmie (1998; cf. also Harstine 2013) provided us with the key information about the character of God in John. A comprehensive conference on the topic of

1 Thompson (2001) argues throughout her book that the description theocentric fits the contents of the Gospel better than Christocentric. 
God in John was also held January 2017 in Vienna as part of a project on God in John, especially in light of German research. ${ }^{2}$

In this essay I want to focus on one aspect related to the term $\theta \varepsilon$ co (god) in the Gospel of John, namely the use of the term to describe Jesus. ${ }^{3}$ In the Gospel there are three such instances, namely John 1:1 ('Ev ả $\rho \chi \tilde{\eta} \tilde{\eta} v \dot{o}$

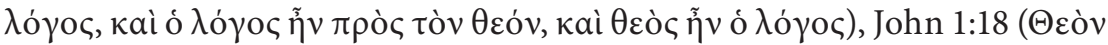

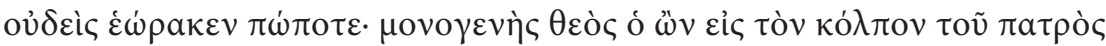

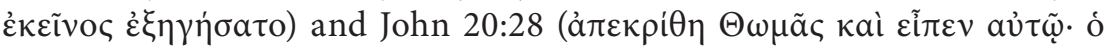

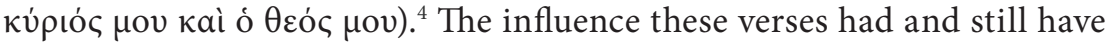
on the formulation of Christian confessions and the general perception of Christianity goes without saying. However, it remains an enigma what these references exactly mean, especially theologically. In both cases in John 1 it is used in direct proximity, the same word referring to God the Father ${ }^{5}$, posing the question whether the semantic reference is the same. In chapter 20:28 it is used with the word кúpı́c, which may also be used for multiple references, inter alia to refer to Yahweh.

The aim of this article is not to solve this enigma, but to reflect specifically on the use of the term in the context of the Gospel itself. Dogmatic positions will not be considered. In the first place a brief look will be taken at each of the three uses in their context. It must be emphasized that full exegesis of each passage will not be attempted, but only data relevant for the development of the argument will be mentioned. This information will then be considered in light of related remarks in the rest of the Gospel. The basic contention is that the word $\theta$ có $\varsigma$ is not restricted to a single reference, ${ }^{6}$

2 Kelly and Moloney (2003) approaches the theme from the perspective of how God is experienced in different ways in and through the Gospel.

3 Cf. Thompson (2001) and Bauckham (2007:239-252) for discussions on this issue. Both emphasize the importance of the issue, and the latter is of opinion that the relationship between Johannine Christology and monotheism is usually not adequately understood.

4 There is also a reference in 1 John 5:20, but that is not going to be discussed here.

5 This term is used in this essay to essentially distinguish the Father from the Son, both of whom John refers to with the term $\theta \varepsilon$ óc.

6 Cf. Thompson's (2001:17-55) comprehensive discussion on the meaning of the word "god". 
but indicate unity, not on ontological level, but on functional, relational (social) and mental ${ }^{7}$ level.

\section{Jesus called $\theta \varepsilon \dot{c} \varsigma$}

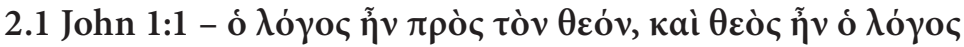

The importance of John 1:1 is perhaps only matched by the bulkiness of discussions in secondary material on this verse. ${ }^{8}$ At first the special position of this verse should be noted: it is the introductory verse of the Gospel, and introductions in ancient documents inter alia often served as summarizing and preparatory statements implicating what is to follow in the rest of the document. ${ }^{9}$ In such a context a remark is made that reminds of a riddle ${ }^{10}$, due to the apparent logical contradiction stating that the Word

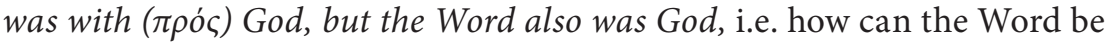
with God but simultaneously be God? It seems that 1:1b refers to a relation between the Word and God (Brown 1971:5; Bruce 1983:31), while 1:1c refers to identity, identifying the Word as God. In light of the function of introductions mentioned above, the (implied) reader may expect that this provocative riddle-like statement might somehow be solved as the Gospel narrative unfolds, which I think indeed happens.

The immediate context should also be carefully observed. In verse 2 the

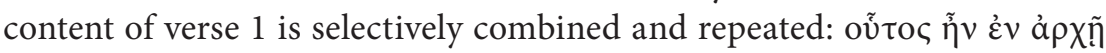

7 What is meant by the word "mental" will be explained as the argument unfolds.

8 A few examples are: Miller (1989), Cf. on the grammar alone, Van der Watt and Caragounis (2009:1-52). Cf. also Van der Watt, Culpepper and Schnelle (2016).

9 This is argued in different ways in Van der Watt, Culpepper and Schnelle (2016). It is also a basic conclusion of Endo (2002:252).

10 Van der Watt (2016:57-78) argues that the grammar and syntax does not reflect the riddle-like nature of the sentence, but on theological grounds it might be the case. Thatcher (2001:269) seems convinced that the Fourth Evangelist "must have been relatively familiar with oral riddles and riddling sessions." Leroy (1968:6-7) argues that the misunderstandings in John are the result of riddles. Thatcher (2000:179). On pages 181-83 he gives four criteria he uses to identify riddles: (1) if the narrator states that the character intends to blur the referent by way of $\pi \alpha \rho$ o $\mu$ ia, (2) if the character indicates that he or she is intentionally ambigious, (3) if the audience is confused and finds the referent ambigious, and (4) if the words are used contrary to the normal conventions of language or logic. Cf. also Thatcher (2006). Thatcher, in his ground-breaking works on riddles in John, does not treat 1:1 as riddle, mainly because of his definition of riddles and his approach of focusing on Jesus. 


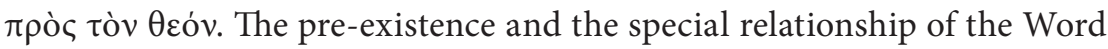
with God (the Father) are emphasized, while the remark that the Word was God is not repeated. Schnelle (2016:49) opines that verse 2 underlines the divine origin of Jesus, "es verweilt bei Gott und beginnt von dort sein Wirken". This leads to 1:3 (cf. also 1:10) where there is reference to the Word as creator, with creation normally regarded as function only of

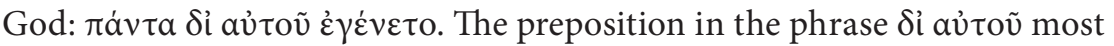
probably refer to agency ${ }^{11}$ that functionally links the action of the Word with the generally accepted action of God alone (Bauckham 2007:240-241; Smith 1999:50; Endo 2002). The overlap between the Word and God in this context is on a functional level, being able to do the same thing. ${ }^{12}$ This might explain why the Logos is not described as God in verse 2, which reaffirms what is said in verse 1 - the Logos can be described as God, because it does what only God can - the Logos creates. ${ }^{13}$

What is clear is that the word $\theta \varepsilon$ co is used for two entities, the Logos and God the Father. In light of this problem, Bauckham (2007:241) argues that the pronoun for Logos in verse 1-5 should be "it" and not "he", since these verses echoes the creation account of Genesis, as his student Endo (2002) also argued at length. ${ }^{14} \mathrm{He}$ argues that since there are no direct references to the Word as person in these first few verses the reference to the Word should be understood against the background of Jewish statements about

11 Cf. Arndt (2000:225) - it is also remarked that "Christ as intermediary in the creation of the world". The creative function of Jesus seems to have been know wider in early Christianity (cf. 1 Cor 8:6; Col 1:16). The preposition can also be described as referring to an instrument, but it basically implies the same as agency.

12 Neyrey (2007:42) even goes so far as to claim that the name $\theta \varepsilon$ ó s specifically refer to "God's creative power". The discussion of Bultmann (1978:5-15) on these verses is still worth reading. He considers the use of the term $\lambda$ ó $\gamma$ oc from different angles.

13 Schnackenburg (1968:234-235) underlines that one should not restrict the use of $\theta \varepsilon$ có to just a function, since the function is possible on the basis of "his divine being". Lindars (1987:77) seems to move into a play of words that sounds remarkably dogmatic: "The eternal being of God includes the Word...Though inseparable from him in essence, it can be distinguished from him conceptually; it thus partakes of the nature of God, preserving Jewish monotheism".

14 Keener (2003:373-374) points out that $\theta \varepsilon$ ć might also be translated as "divine", thus distinguishing God the Father from the Logos. He suggests that it should be expressed as "fully deity but not the Father". 
creation in which agents like God's word or wisdom is common. ${ }^{15}$ This preserves the Jewish monotheism in these verses, since "as God's own word, it was intrinsic to God's own unique identity ... that all things came into being through the Word is precisely to categorize the Word as belonging to the identity of God rather than to creation" (Bauckham 2007:241). ${ }^{16}$

A basic point Bauckham makes is that Jesus forms part of the identity of God and therefore does not stand over and against God. He (2007:239) opines,

a Christology of divine identity, in which Jesus is understood to be included in the unique divine identity of the one and only God, the God of Israel, is pervasive in the New Testament writings... they use these well understood categories of Jewish monotheism in order to apply them also to Jesus, thus including him in the unique divine identity.

In his view, this secures the idea of Jewish monotheism.

Bauckham's view does not fully solve the essential problem that Thompson (2001:5-11) also refers to, namely, that the Logos is contextually identified with a person, namely, Jesus. This person is called God, the Son of God the Father. Even if the first few verses of John do not directly identify the Word with Jesus, the subsequent verses of the Prologue makes this clear and therefore semantically implicates Jesus as the Logos, also there, which makes Bauckham's sharp distinction problematic. ${ }^{17}$ The issue is still how

15 Keener (2003:367-368, 370-372) gives due attention to Wisdom or Torah and creation. Cf. also Thompson (2001:43-46) for wider use of the word god in Jewish literature. Typical to his approach, Bultmann (1978:14) interprets the use of $\lambda$ ó $\gamma \circ$ in terms of a relatively early oriental Gnosticism that are expanded within the framework of Old Testament creation beliefs.

16 The view of Thompson (2001:42) should be noted, namely, that the word god was used widely even to refer to humans in the ancient Greek and Hellenistic worlds. Applying it to a single monotheistic God was not the beginning of the use of the word, but a development, especially in Judaism. The word is used, even in the New Testament as predicative ("divine") and as an appellative ("the only one properly called God" Thompson 2001:44). Obviously, this placed restrictions on the use of the word "god" but also offered some interpretative opportunities in the use of this word, something that seems to have happened in John, as will be argued.

17 The reader with the first reading might not be sure who the Logos refers to but will learn that very soon through the following verses of the Prologue, semantically adjusting his or her opinion about the first verses. Implicit re-reading will take place. 
two persons can be accommodated by the single word $\theta \varepsilon$ ó $\varsigma$. In 1:1-3 the solution seems to lie within the functional overlap based on a unique relationship, based on pre-existing shared presence.

\subsection{The unique God who makes God known - John 1:18}

John 1:18 is a key verse in John but is complex as well as problematic. Firstly, there is the text critical problem whether the text should read,

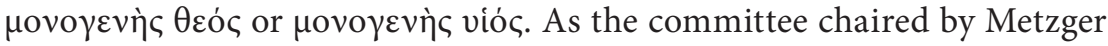
pointed out, the latter is the easier reading and could be the result of scribal assimilation, while the former, in light of 1:1, looks the more "primitive" and more difficult reading (Metzger 1994:169-170). ${ }^{18}$ Although hundred

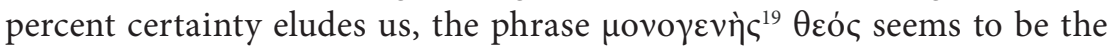
preferable reading and will therefore receive due attention here. ${ }^{20}$

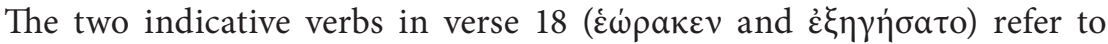
processes of gaining knowledge - knowledge of God cannot be directly obtained by observing him, which implies that he should therefore be made known (observable) in another way, i.e. by somebody else. This somebody is

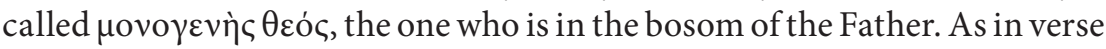
1 the word $\theta \varepsilon$ co $\varsigma$ is again used to refer to two Persons. These two persons are however, again as is the case in verse 1, intimately related, as the expression

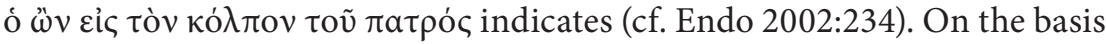
of their intimate relation, Jesus is able to authentically represent God for who and what he is. In other words, in Jesus, the unique God, the Father is made known. This use of the word $\pi \alpha \tau \eta \dot{p}$ (father) is of significance, since it distinguishes the two Persons on the basis of a familial relationship: father son (implied). They are not the same, but nevertheless the word $\theta \varepsilon$ ó is used for both. This implies that the word $\theta \varepsilon$ ó is used to refer to something that

18 Commentators like Bultmann (1978:55-56), Brown (1971:13) or Lindars (1987:98-99) prefer vióc, while others like Schnackenburg (1968:279-281), Barrett (1978:169), Smith (1999:62) or Keener (2003:425-426) argue for $\theta \varepsilon$ ć $\varsigma$ as the best option, as the latest editions of the Greek New Testament suggest.

19 I agree with Brown (1971:13) that this term refers to uniqueness rather than to procession.

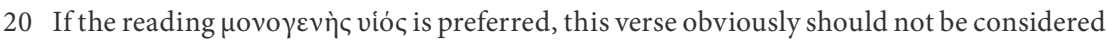
as reference to Jesus as God. Since the remark in 1:1 largely communicates what 1:18 also want to say, the theological loss would not be severe and will not devalue the argument in this essay. 
the two persons share that indeed allows for $\theta$ có $\varsigma$ to be applied to both but does not make them ontologically one single person (so also Bauckham 2007:251). A clue lies in the fact that this is done in a context where the intimate relationship between the two is emphasized and where the one (Jesus) can authentically represent the other (the Father). It seems plausible that this particular use of the word $\theta$ có $\varsigma$ should be understood within this relational and functional context.

\subsection{My Lord and my God - John 20:28}

In his confession, forming the apex of the narrative, Thomas refers to Jesus as his Lord and God (20:28 - cf. also Endo 2002:252). Two themes dominate this scene, namely, the tension between unbelief and belief and the appearance of the resurrected Jesus whose presence changes unbelief to belief (cf. Brown 1972:1045-1046). This appearance of Jesus who was dead and buried in physical form convinces Thomas to confess him as his Lord and God. What lies behind this confession that Thompson (2001:55; cf. also Keener 2003a:1211) describes as the "summary and elaboration of the work and person of Jesus through the Gospel"?

This confession echoes the basic theological claim of John that Jesus as creator has power over life and death. In Ch 5 Jesus heals the cripple and is then confronted by the Jewish opponents for doing it on the Sabbath, thus not following the Jewish way of a law-abiding life. Jesus' answer is telling: o

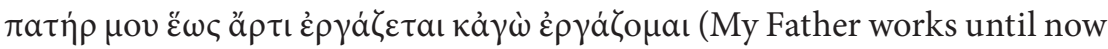
and I am working), functionally linking what he does with the Father. The response of the Jewish opponents is that he does not only break the Sabbath, but also calls God his father and thus makes himself equal to God (i.e. kaì $\pi \alpha \tau \dot{\varepsilon} \rho \alpha$ ídı again telling. By way of an educational imagery he claims that his Father loved him and he showed him everything and gave him the power to give life, and ultimately to judge. This will obviously result in the fact that he will be honoured as the Father is honoured, a sign of recognition of his divine identity according to Bauckham (2007:243 - cf. 5:19-23).

The answer of Jesus to the accusation that he makes himself equal to God is therefore that he was educated by the Father and can therefore functionally do what only God can do, namely, he can give life. This is possible because of their loving relationship (cf. also 10:17-18 - Bauckham 2007:243). As 
Jesus says: "For as the Father raises the dead and gives them life, so also the

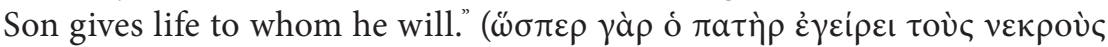

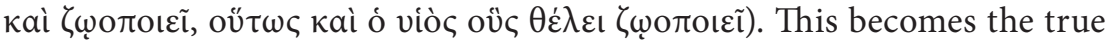
test of Jesus' claim to be equal to God. He should be able to do what only God can do.

What should be noted here is the clear distinction that is maintained between the Father and the Son. The Son only does what he sees the Father doing, thus copying his deeds like a good pupil. Functionally they act likewise, but ontologically they are to be distinguished.

This ability of Jesus to give life becomes a major theme in the rest of the Gospel. In 10:17-18 he remarks, "For this reason the Father loves me, because I lay down my life that I may take it up again. No one takes it from me, but I lay it down of my own accord. I have authority to lay it down, and I have authority to take it up again. This charge I have received from my Father" ${ }^{21}$ Here his ability, even over his own life ( $\left.\psi \bar{v} \chi \eta^{\prime}\right)$ is described, again within his relationship with the Father who loves him and gave him the commandment to do exactly this. This echoes what is claimed in Chapter 5.

His ability over life and death is double underlined in Ch. 11 where he makes the powerful "I am" remark (11:25-26): "I am the resurrection and the life. Whoever believes in me, though he die, yet shall he live, and everyone who lives and believes in me shall never die. Do you believe this? (ESV)" ${ }^{22}$ He then raises Lazarus. According to what is claimed in Ch. 5 this should serve as proof of his divine nature, being equal to God. What is claimed there is proven here.

And this brings us back to the Thomas episode. When Jesus does what is claimed in chapter 5, even more, when he does what he said in 10:17-18, namely, raising himself, showing that he is the resurrection and life (11:2526) there can be no doubt in Thomas' mind that Jesus is Lord and God. In light of the strong development of the theme in John, any interpretation

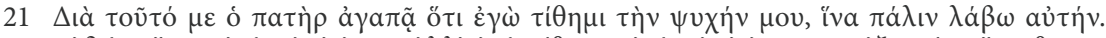

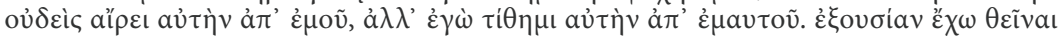

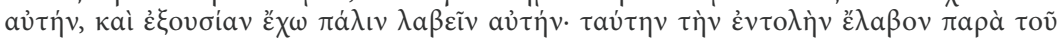

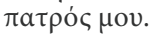

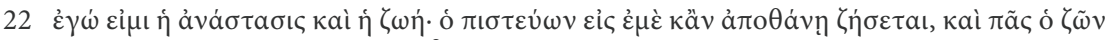

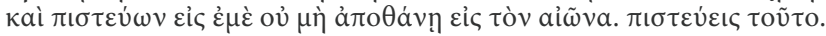


that does not keep the distinction between God the Father and his Son in mind here, should be regarded as flawed..$^{23}$ Jesus rose because the Father gave him the commandment and power to do so $(5: 19-23 ; 10: 17-18)$. Again, the word $\theta \varepsilon$ ó seems to refer to two Persons (implicitly) who functionally act in unison, based on an intimate relationship.

Another passage should also be considered here, namely, the discussion in 10:22-39 between Jesus and the Jewish crowd in the colonnade of Solomon in the temple. The crowd was enquiring about Jesus' identity with the words, "How long will you keep us in suspense? If you are the Christ, tell us plainly". In his response Jesus returns to the imagery of the sheep and shepherd and explains that He protects his sheep like the Father, because they are one (10:30). The unity is again functionally based - they both protect the sheep in a similar way. The response of the crowd to the reference to the unity is that they want to stone Jesus. In line with his functional statement in 10:28-29 he asks them for which of the many good

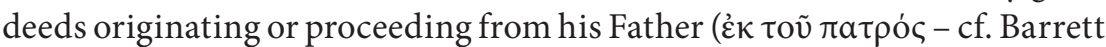
1978:383; Schnelle 2016:237) do they want to kill him. This question goes back to the basic assumption, already stated in 5:19-23 that Jesus is on the divine side because the Father showed him everything and he consequently says and does what the Father requires. If they can point out which of the many deeds do not fulfil these requirements, their plan to stone him might make some sense, which it does not in light of his many good deeds. ${ }^{24}$

The response of the Jewish crowd is ironic - they steer away from the deeds, which by implication do not provide a basis for conviction, rather accusing

23 Brown (1972:1047) wants to tone this remark of Thomas down by arguing that although the remark is made in language "in which Israel addressed Yahweh" it should be noted that it is done in a confession of faith. It should not be seen as a dogmatic expression but occurs in a liturgical and cultic context: "It is a response of praise to the God who has revealed Himself in Jesus". In light of the use above explanation this view does not seem convincing. To my mind the restriction of the term to liturgical use does not give it "another" meaning neither does the text indicate that it is not said of Jesus but is meant for honouring the Father. Schnackenburg (1976:332-333) is also careful in explaining the use of the word "god" in this context. He emphasizes that Thomas says "my" God, personalizing it, explaining that for Thomas the consequence of the resurrection was realizing that "Jesus is of divine essence, in him God himself comes to him, he is for him God in his majesty, power and love".

24 The same argument is used against the servant of the High Priest that hit Jesus $(18: 22-24)$. 
Jesus of blasphemy (most recently in 10:30) for making himself God

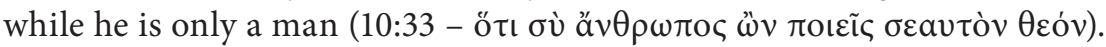
Apparently, they acknowledge that Jesus claims divinity, but ironically miss the point that if they look at the many good deeds of the Father that Jesus performs, the claim Jesus makes would seem obvious. ${ }^{25}$

In the discussion in 10:33 their accusation is even more damning than in 5:18. In 5:18 they claim that Jesus makes himself "equal" to God ( $\pi \alpha \tau \dot{\varepsilon} \rho \alpha$

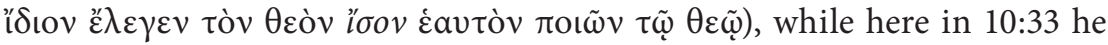

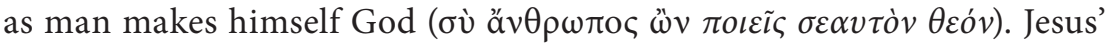
reaction should be carefully noted.

Jesus' remark quotes Ps 82:6 $6^{26}$ which deals with God addressing the divine council of "gods" who should have judged righteously in favour of the oppressed and those suffering. In verse 6 God says the following: "I said, 'You are gods, all sons of the Most High' " (દ่ $\gamma \grave{\omega}$

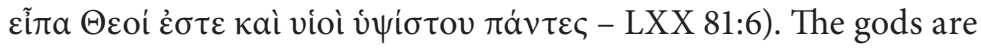
called "sons of the Most High". Clearly the word $\theta \varepsilon o$ i is used here to refer to other figures who are functionally judging on behalf of God, who are supposed to functionally performs his judgment, indeed, to whom God's word came, as Jesus puts it (10:35). ${ }^{27}$ As gods or sons

25 Cf. also Bultmann (1978:296); Schnackenburg (1980:309-310); Keener (2003:826-827); Bauckham (2007:250). This is the same "blindness" that is found in the argument between the Pharisees and the healed blind man in 9:24-24 and is in John a characteristic of the Jewish opponents.

26 Tate (1998) underlines the complexity as well as diverse ways of interpreting Ps 82 in his discussion of Psalm 82. Bultmann (1978:296) opined that the original context of the Psalm is ignored in John.

27 Although it is an important point, it is not necessary to determine the exact reference of "gods" here. Tate (1998:340) discusses the possibilities. He indicates that the idea that there is reference to the judges or officials of Israel is an opinion that goes back a long way. Bultmann (1978:296) also opines that the word "god" here refers to humans while Barrett (1978:384) thinks that the reference here is to Israel in line with rabbinic interpretations (cf. also Bultmann 1978:296). Tate (1998:340), however, rules out the possibility that the reference here could be to humans. He however points out that it is not a matter of gods vs. humans, but both are involved. Earthly judges and leaders are expressing divine wishes. Tate (1998:341) remarks: "The gods as patrons of the various nations were responsible for the type of kings, judges, and officials they appointed and empowered; however, the gods, not even Yahweh, do not act directly. Their will is administered by human agents, who are extensions of the divine presence in earthly affairs. Thus, the judgment of the gods is at the same time a judgment of their human agents". 
they had divine duties and responsibilities. Within this argument of Jesus, the word $\theta \varepsilon$ ó $\varsigma$ should not be restricted to the monotheistic God, but can, according to the law of the Jews, be applied in a broader way - there are others in the presence of God who are called gods and sons that impact the earthly reality of the needy and poor through their deeds (cf. Barrett 1978:385). As Thompson (2001:43) has shown, the wider use of the word "god" to apply to humans or angels was not strange or prohibited, even in Hellenistic Judaism.

In his argument Jesus does not use the word $\theta$ có $\varsigma$ for himself, but echoes another concept in Ps 82:6, namely that he, as the sent one, is the Son of God, and by implication, based on 82:6 might also be called $\theta$ cóc. Lindars (1987:374) points out that in Psalm 82:6b the "gods" are also called "sons" which makes Jesus' response even more acceptable. Jesus then reverts back to the point the Jewish opponents did not recognize, namely, that he is doing the works of the Father. The Jewish opponents do not want to make the logical conclusion that based on his deeds Jesus can claim that he and the Father are one, indeed that "the Father is in me and I am in the Father" $(10: 38)$. His emphasis on the fact that if they do not want to believe what he claims, they should look at his works and make their own conclusion, implies that works reflect identity and therefore reflects the truth. The emphasis on knowing and understanding ( $\gamma \nu \tilde{\omega} \tau \varepsilon$ кaì $\gamma \iota \nu \omega \sigma \kappa \eta \tau \varepsilon)$ the words implies this process of linking the deeds to the identity of Jesus. Unfortunately, the Jewish opponents again did not understand the link between the works and the identity of Jesus, something that was clearly explained to them by the healed blind man $(9: 28-34){ }^{28}$

Reflecting briefly on the contribution of the above remarks in Chapter 10, the pattern is more than clear: the word $\theta \varepsilon$ co may be used for the monotheistic God but could be used in a wider sense of his sons also, especially of his Son, who performs exactly what the Father requires of him, even more than

28 According to Thompson (2001:45) the issue whether heavenly beings ought to be called gods in the Jewish tradition is not a matter of the use of the word itself, but "what sort of honours or veneration they merit, what functions they exercise, and, perhaps most importantly, how they came to exercise those functions". If this is the case this implies that the Jewish opponents should have been able to understand the argument of Jesus. 
that, he does what only the Father can do, namely, giving life (10:17-18). ${ }^{29}$ $\mathrm{He}$ and the Father are indeed one, because they function as one. ${ }^{30}$

This brings us to another interesting issue that is prevalent in the sociocultural and spiritual spheres in ancient times, namely, the constant danger a ruler faced of being ousted by those around him. Coups were a constant danger within ancient contexts of power. ${ }^{31}$

According to the Johannine narrative Jesus is perceived by his Jewish opponents as threatening the position of their monotheistic God. His opponents clearly made this point throughout the Gospel. Accusing Jesus at the climax of his trial these Jewish opponents insisted, "We have a law, and according to that law he (= Jesus) ought to die because he has made himself the Son of God" (19:7). This echoes their perception of Jesus from the early stages of the narrative. In 5:18 the narrator informs the implied reader, "This was why the Jews were seeking all the more to kill him, because not only was he breaking the Sabbath, but he was even calling God his own

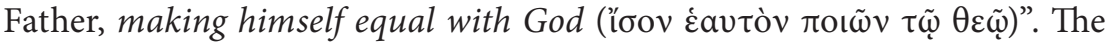
charge is even clearer in the discussions in 10:33 (cf. also 10:36): "It is not for a good work that we are going to stone you but for blasphemy, because

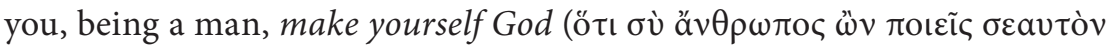
$\theta \varepsilon \dot{v} v)$. These remarks clearly express the view of the Jewish opponents that Jesus tries to threaten the position of God. Within a Jewish context no other

29 The question might be asked whether this implies that if believers do what the Father and Son requires they also become gods? John could easily have claimed that in the light of his remark that in Ps 82:6 people are indeed called Gods as well as the fact that believers share in the divine qualities like life or are children of light. However, in spite of the option to do that, John does not go that far and there are even indications in the Gospel that he does not intend that since believers need the Paraclete as presence from above. As children of light and having life, they partake in the divine family of God. They are however not called gods, neither are they "from above" like Jesus. John clearly restricts his argument to the Father and Son.

30 The unity between the Father and Son is inter alia described in more detail in 14:1-24 or 17:9-23 and confirms the functional unity between the Father and Son, based on being one mind and will. The distinction between the Father and Son is clearly maintained in these passages. Cf. also Bauckham (2007:251) and Endo (2002:237).

31 The material in the section that follows was also used in an essay on the son as the representative of the Father, since it was also relevant to the argument in that essay that is in the redaction process when this essay was completed. The title of the essay is, "An attempted coup? No, the Father is made known by his Son" and will be published in a volume consisting of the papers read at the conference in Vienna in January 2017 on the concept of God in John. 
being or god or idol are allowed to threaten the unique position of God. This should be appreciated against the fact that within the Jewish tradition and according to the first four commandments the honour of God as only God must be protected. There was no place for another powerful divine being next to God, no matter who they were or where they came from. In their history Israel was constantly under pressure to turn to other divine figures and consequently to turn away from their own God, something that incurred the wrath of God. ${ }^{32}$ It should however be noted that Hellenistic Jewish authors like Philo did allow for the word "god" to be used of humans (cf. Thompson 2001:35-48). The position the Jewish opponents take either ignores these views or interpret Jesus not in the context of what Philo and others presented, but as direct opponent of their monotheistic God and not simply as somebody performing God's deeds. In the latter case Jesus might obviously regarded as direct threat.

In the light of the above insinuations by the Jewish opponents about Jesus making himself God, possibly influenced by ancient perceptions of conflicting divine figures including angels, I would like to suggest that Johannine rhetorical descriptions of the relationship between God and Jesus were inter alia influenced by and aimed at countering the idea that Jesus might somehow threaten the position of God. John uses metaphors like Father and Son, the Son loving (i.e. obeying) the Father, or the mission of the Son, doing nothing of his own inter alia as indications that Jesus poses no threat to his Father, excluding a possible "coup", as his opponents want to suggest when they claim that he is making himself God over and against their only God.

I would like to consider this apparent tension within a scenario that relates to perceptions regarding both the necessity and danger within a context of monotheism of allowing other powerful beings into the divine presence. The emergence of monotheism went hand in hand with specific developments in angelology (Van der Watt 2011:185-204). Scholars like Meier (2009:1167), Di Tommaso (2009:1167-1173), Corbin (1981:100) and Tuschling (2007) point out that with monotheism gaining prominence, the

32 Brueggemann (2008) argues throughout his book that the tension between a disobedient people and their God, expecting them to honour the covenant is a basic structure in the development of the message of the First Testament. 
role of angels increased in importance ${ }^{33}$ in order to ensure the continuing "presence" of God on earth, even though it was indirectly. Concepts like the ancient councils of gods, sons of gods, holy ones were common in ancient Eastern contexts, metaphorically describing the divine world in terms of ancient royal courts. With single powerful rulers the need for numerous servants and representatives existed in order to represent the ruler in his kingdom, since he cannot physically be omnipresent. Di Tommaso (2009:173) notes that especially in post-exilic times the idea of the monotheistic God's transcendence and "the corresponding sense of his disassociation from the everyday process of the world" stimulated the idea of heavenly beings as divine agents who act on behalf of God.

Based on this metaphorical application of powerful single rulers in ancient royal courts, the monotheistic God was described as having servant-angels like a king had servants who served not only him in his court, but also served as his presence in the outside human world. Tuschling (2007:1) underlines that these servants of God expressed different attributes of God in different ways, i.e. as servants they carried out their commissions (Meier 2009:1169) by doing what God requires, ensuring the omnipresence of his divine power. This also applied to John's narrative; the transcendental God, whom nobody has seen (1:18), had to reveal himself, show his power and omniscience and emphasize his majesty, and this was inter alia achieved through mediatory beings (Tuschling 2007:5-8). In John 1:18 this revelation of the unseen God is delineated and restricted, when the "firstborn" God, Jesus, will make his Father known.

A real threat, however, existed within ancient royal courts, namely, overthrowing the king, which was often executed by a strong figure within the court. This pattern was also perceived possible in the divine world with its gods and angels and was therefore a concrete possibility within the metaphorical application within the framework of a monotheistic God. This is indeed what happened within the (Christian) tradition in which John finds himself, as is evident in the presence of the devil or Satan as opposing

33 The reason was that within monotheism the superiority of God increased to such an extent that other gods or transcendental, supernatural figures were totally subordinate - although their presence is still attested, they now fulfill secondary roles and served as messengers or representatives for God. Cf. Meier (2009:1167-1168). 
prince or leader of this world $(12: 31 ; 14: 30)$ who has significant opposing power. This opposing power should be dealt with in the manifestation of the royal power of God on earth $(12: 31 ; 14: 30)$.

The arguments above suggest the plausibility of a conceptual interrelatedness between the view of the Jewish opponents that is formulated in terms of Jesus threatening the position of their God and the description of the relation between the Father and the Son. Within the dynamics of such a narrative it indeed seems highly plausible to me that the danger of Jesus threatening God or even replacing him might have been an (by far not the only) underlying dynamic in the development of Johannine theology, especially in light of the conflict between Jesus and his Jewish opponents described in John. Although I hesitate to speak of the clear intention of the author, as the danger of intentional fallacy consistently warns us, the rhetorical and argumentative weight of the evidence described above leaves me with a more than strong suspicion that such a danger was indeed countered by John through his choice of themes and concepts, his presentation of the presence of Jesus, not the least his choice for describing the relationship between Jesus and God in terms of a Father that has a Son, with the social conceptions and possibilities associated with such a metaphor. ${ }^{34}$ The central structural feature of the Gospel, namely, the mission of Jesus, where the one who sends is more important than the one sent and absolute obedience is required of the one sent, also underlines the non-threatening position of Jesus. Everything he does and all his power comes from the Father based on a loving relationship. As Thompson (2001:235) puts it, "the Gospel has made it clear that the identity of Jesus cannot be fully comprehended unless grasped as the manifestation and revelation of God".

Within such a metaphorical description the Son can never become the Father but will always remain his Son. Within this reality John describes Jesus as the ideal loving and obedient Son who always honours and glorifies his Father, doing exactly what the Father asks of him. Even Jesus' activities on earth are overwhelmingly emphasized as being referential and

34 Obviously, the challenges of describing the Christological dynamics in clearer and more exact detail is well known, since it forms one of the pillars of Johannine Christological debates. This is not the focus of theme here and will therefore not receive any further attention, since the purpose here is theo-logy rather than Christ-ology. 
transparent and are regarded as misunderstood if they are not interpreted as showing and revealing not Jesus, but the Father. The imagery of mission emphasizes the mediatory role of Jesus even further, since the sender is more important than the one sent. Jesus in no way threatens the Father but does claim to be in an intimate and unique relation to the Father, something nobody else can claim. With the way wisdom, for instance, functions within the godhead, the idea of the Father's Son being with him would fall within acceptable perceptions.

\section{Some concluding reflections}

In John we have a refined thought pattern when it comes to the use of the word $\theta \varepsilon$ ćc. Briefly it may be described as follows:

The use of the word $\theta \varepsilon$ c $\varsigma$ is not restricted to the monotheistic God, but allows for a wider use, including sons of God or people performing actions on behalf of God. According to Ps 82 the judges may be called gods for functional reasons, i.e. because they did what God required - they judge (as part of the divine council). In similar fashion Jesus functionally did the works of the Father, importantly, what he does is what only God can do, i.e. these are divine priorities - namely to give life and judge eschatologically. This is what the Father showed him and the power and authority the Father gave the Son. As his unique Son Jesus must make the Father known. The Father is thus revealed by his pre-existent Son, who is one with him because he does nothing of his own, but just what the Father commanded him. This is his mission.

This is however only possible because of the intensely close relationship between the Father and Son. He is with the Father, yes, at the bosom of the Father who loves him as his unique Son and shows and shares everything with him - they are both from above and not from below. He is not only functionally one with the Father but their close relationship also illustrates their unity, a unity that never threatens either one of them. At this point Bauckham (2007:251) also acknowledges that John moves beyond the categories of Jewish monotheism by redefining divine identity "as one in which Father and Son are inseparably united in differentiation from each other". In this regard Keener (2003:425) opines that connection between the Father and Son is not simply relational, but also consists in their 
"shared nature and similar role". Obviously, relationship, sharing in the divine nature and functionality cannot be separated. The one is possible because of the other.

The term $\theta \varepsilon$ os is indeed used for both the Father and the Son to indicate their divine unity expressed in their functional and relational (social) unity. ${ }^{35}$ This Immanenz or unity implies unity of soul and mind - Jesus knows the Father intimately ${ }^{36}$ and therefore expresses and explains him accordingly, i.e. revealing his will, aims, timetable, love, deeds. ${ }^{37}$ Jesus' words are the Father's words and Jesus' deeds are the Father's deeds.

Although the Jewish opponents might think that Jesus threatens God, the ideological language and choice of imagery (i.e. mission, family) used in the Gospel rule this out. Jesus is the unique One, also called God, who reveals his Father, who is his God, the One who empowered him, sent him, remains with him as his Father, judges with him. In response Jesus reveals the Father, obeys the Father and glorifies the Father.

\section{Bibliography}

Arndt, W., Danker, F. W. and Bauer, W. [BDAG] 2000. A Greek-English lexicon of the New Testament and other early Christian literature. Chicago: University of Chicago Press.

Barrett, C. K. 1978. The Gospel of St John. London: SPCK.

Bauckham, R. 2007. Monotheism and Christology in the Gospel of John. In: The testimony of the beloved Disciple, idem. Grand Rapids: Baker, 239-252.

Brown, R. E. 1971. The Gospel according to John, Vol 1. London: Chapman.

35 Thompson (2001) underlined the functional and relational aspects as expression of the divine nature of Jesus.

36 Bauckham (2007:240) interprets this within the framework of the Jewish way of understanding monotheism, allowing for the word of God and his wisdom to be active with him at creation. In this way he can establish Jesus as fully and truly divine. $\mathrm{He}$ opines that this proves that "divine Christology is not incompatible with Jewish monotheism". Cf. Thompson (2001:47-48) who also argued in this direction.

37 Schnackenburg (1968:233) interprets the strict union between the Father and Son in terms of union in "thought, will and action". 
Brown, R. E. 1972. The Gospel according to John, Vol 2. London: Chapman.

Brueggemann, W. 2008. Old Testament Theology: An introduction. Abingdon Press: Nashville.

Bruce, F. F. 1983. The Gospel of John. Grand Rapids: Eerdmans.

Bultmann, R. 1978. Das Evangelium des Johannes. Göttingen: Vandenhoeck \& Ruprecht.

Corbin, H. 1981. Nécessité de l'angélologie. In: Le paradoxe du monothéisme. Paris: L'Herne.

Dahl, N. A. 1975. The neglected factor in New Testament Theology. Reflections 75, 5-8.

Di Tommaso, L. 2009. Angels in Judaism. In: Klauck, H.-J., et ali. (eds.) Encyclopaedia for the Bible and its reception, vol. 1.Berlin: De Gruyter. 1167-1173.

Endo, M. 2002. Creation and Christology. Tübingen: Mohr Siebeck.

Harstine, S. 2013. “The Fourth Gospel's characterization of God: A rhetorical perspective". In: C.W. Skinner (ed.). Characters and characterization in the Gospel of John. Londen: Bloomsbury. 131-146.

Keck, L. 1986. Toward the renewal of New Testament Christology. NTS 32:362-377.

Keener, C. S. 2003. The Gospel of John. A commentary. Vol. 1. Peabody: Hendrickson Publishers.

Keener, C. S. 2003a. The Gospel of John. A commentary. Vol. 2. Peabody: Hendrickson Publishers.

Kelly A. J. and Moloney, F. J. 2003. Experiencing God in the Gospel of John. New York: Paulist Press.

Leroy, I. H. 1968. Rätsel und Misverständnis. Bonn: Peter Hanstein.

Lindars, B. 1987. The Gospel of John. Grand Rapids: Eerdmans. 
Meier, S. 2009. Angels in the Old Testament. In: Klauck, H.-J., et ali. (eds.). Encyclopaedia for the Bible and its reception, vol. 1. Berlin: De Gruyter. 1167.

Miller, E. L.1989. Salvation History in the Prologue of John. Leiden: Brill.

Neyrey, J. H. 2007. The Gospel of John. Cambridge: Cambridge University Press.

Schnackenburg, R. 1968. The Gospel according to St. John. Vol 1. London: Burns \& Oats.

Schnackenburg, R. 1976. The Gospel according to St. John. Vol 2. London: Burns \& Oats.

Schnackenburg, R. 1980. The Gospel according to St. John. Vol 3, London: Burns \& Oats.

Schnelle, U. 2016. Das Evangelium nach Johannes. Leipzig: Evangelische Verlagsanstalt.

Smith, D. M. 1999. John. Nashville: Abingdon Press.

Tate, M. E. 1998. Psalms 51-100, Word Biblical Commentary, Vol. 20. Dallas: Word.

Thatcher, T. 2000. The Riddles of Jesus in John: A Story in Tradition and Folklore. Atlanta: SBL.

Thatcher, T. 2001. The Riddles of Jesus in the Johannine Dialogues. In: Fortna R.T. and Thatcher, T. (eds.). Jesus in Johannine Tradition. Louisville: Westminster John Knox. 263-80.

Thatcher, T. 2006. Jesus the Riddler: The Power of Ambiguity in the Gospels. Louisville: Westminster John Knox.

Thompson, M. M. 2001. The God of the Gospel of John. Grand Rapids: Eerdmans.

Tuschling, R. M. M. 2007. Angels and Orthodoxy. Tübingen: Mohr Siebeck.

Tolmie, D. F. 1998. The characterization of God in the Fourth Gospel. JSNT 69: 57-75. 
Van der Watt, J. G. 2011. Angels in the Gospel according to John. In: Journal of Early Christian History. 1(1): 185-204.

Van der Watt, J. G. 2016. John 1:1 a "Riddle"? Grammar and Syntax Considered. In: The Prologue of the Gospel John: Its literary, theological and philosophical contexts. Papers read at the Colloquium Ioanneum 2013. Tübingen: Mohr Siebeck. 57-78.

Van der Watt, J. G. and Caragounis, C. 2009. The Grammar of John 1:1. Filologia Neotestamentaria. 22, 1-52.

Van der Watt, J. G., Culpepper, R. A. and Schnelle, U. (eds.), 2016. The Prologue of the Gospel John: Its literary, theological and philosophical contexts. Papers read at the Colloquium Ioanneum 2013. Tübingen: Mohr Siebeck. 